TRADE AND TRADE POLICY WITH DIFFERENTIATED PRODUCTS:

A CHAMBERLINIAN-RICARDIAN MODEL: A COMMENT

\author{
Svetlana Demidova \\ Kala Krishna \\ Working Paper 12949 \\ http://www.nber.org/papers/w12949 \\ NATIONAL BUREAU OF ECONOMIC RESEARCH \\ 1050 Massachusetts Avenue \\ Cambridge, MA 02138 \\ March 2007
}

The views expressed herein are those of the author(s) and do not necessarily reflect the views of the National Bureau of Economic Research.

(C) 2007 by Svetlana Demidova and Kala Krishna. All rights reserved. Short sections of text, not to exceed two paragraphs, may be quoted without explicit permission provided that full credit, including (c) notice, is given to the source. 
Trade and Trade Policy with Differentiated Products: A Chamberlinian-Ricardian Model:

A Comment

Svetlana Demidova and Kala Krishna

NBER Working Paper No. 12949

March 2007

JEL No. F1

\section{ABSTRACT}

This paper shows that the results of Venables (1987) depend critically on the assumption that there are no fixed costs of trade. The introduction of fixed costs of exporting, while making the model more consistent with the empirical evidence, leads to the opposite conclusion that technological progress in one country cannot harm the welfare of its trading partner. However, the results can be obtained in a richer setting with heterogeneous firms.

Svetlana Demidova

University of Georgia

Department of Economics

Brooks Hall 528

Athens, GA 30602

demidova@terry.uga.edu

Kala Krishna

Department of Economics

523 Kern Graduate Building

The Pennsylvania State University

University Park, PA 16802

and NBER

kmk4@psu.edu 


\title{
Trade and Trade Policy with Differentiated Products: A Chamberlinian-Ricardian Model: A Comment
}

\author{
Svetlana Demidova* \\ University of Georgia \\ Kala Krishna ${ }^{\dagger}$ \\ Princeton University, Pennsylvania State University and NBER
}

December 2006.

\begin{abstract}
This paper shows that the results of Venables (1987) depend critically on the assumption that there are no fixed costs of trade. The introduction of fixed costs of exporting, while making the model more consistent with the empirical evidence, leads to the opposite conclusion that technological progress in one country cannot harm the welfare of its trading partner. However, the results can be obtained in a richer setting with heterogeneous firms.
\end{abstract}

Keywords: Technological progress, fixed costs of exporting.

\section{Introduction}

Venables (1987) studies the impact of differences in countries' sizes and technologies on welfare as well as the consequences of trade policies. He uses the standard monopolistic competition setting with homogeneous firms. A particularly interesting result obtained is that technological progress in the monopolistically competitive industry in one country raises welfare there, but reduces it abroad. $^{1}$

Among the assumptions used by Venables (1987) to derive this result is that there are no fixed costs associated with exporting: the only additional costs paid by firms wishing to export are perunit costs such as those associated with transportation or trade policy. However, this assumption is at odds with the empirical evidence, which shows that exporting firms face significant fixed costs associated with entry into export markets. (See, for instance, Roberts and Tybout (1997).) This leads to the natural question whether adding such costs to the model changes its predictions. In this note, we show that including the fixed costs of exporting into the model developed by Venables $(1987)^{2}$ eliminates the result mentioned above: in the presence of such costs, technological progress in the monopolistically competitive industry in one country cannot result in welfare losses elsewhere.

\footnotetext{
${ }^{*}$ Department of Economics, University of Georgia, 528 Brooks Hall, Athens, GA 30602. E-mail: demidova@terry.uga.edu. Phone: (706) 542 3689. Fax: (706) 5423376.

${ }^{\dagger}$ Department of Economics, Pennsylvania State University, University Park, PA, 16802. Email: kmk4@psu.edu. Tel: (814) 865 1106. Fax: (814) 8634775.

${ }^{1}$ See Proposition 3 on page 708 of the paper.

${ }^{2}$ We use the ideas from the model developed by Venables (1987) in the setting a la Melitz (2003).
} 


\section{The Model}

There are two countries, home and foreign, each of which has the same number of workers, $L$. Labor is assumed to be the only factor of production. ${ }^{3}$ Each country produces a homogeneous good, $N$, under constant returns to scale, a unit input requirement of labor, and conditions of perfect competition. The homogeneous good is chosen as the numeraire, which allows to normalize the wage to unity in each country. In addition, each firm in a country may produce a variety of the differentiated good. Preferences are given by $U=(N)^{1-\beta}(Q)^{\beta}, 1>\beta>0$, where $Q=$ $\left(\int_{v \in \Omega} q(v)^{\rho} d v\right)^{1 / \rho}$ is the sub-utility from consuming $q(v)$ units of each variety $v$ when $\Omega$ is the set of available varieties of the differentiated good. ${ }^{4}$

Denote the domestic price of variety $v$ produced in country $i, i=H, F$, by $p_{i}(v)$ and its exporting price by $p_{x, i}(v)$ Then the cost of a unit of $Q_{i}$ defines the perfect price index in country $i$

$$
P_{i}=\left[M_{i i}\left(p_{i}(v)\right)^{1-\sigma}+M_{j i}\left(p_{x, j}(v)\right)^{1-\sigma}\right]^{\frac{1}{1-\sigma}}, \sigma=\frac{1}{1-\rho}>1,
$$

where $M_{i i}$ is the mass of domestic firms in country $i$, and $M_{j i}$ is the mass of exporters from country $j$ to country $i$. As originally shown by Dixit and Stiglitz (1977), the demand in countries $i$ and $j$ for variety $v$ produced in country $i$ is, respectively,

$$
q_{i}(v)=Q_{i}\left[\frac{p_{i}(v)}{P_{i}}\right]^{-\sigma} \text { and } q_{x, i}(v)=Q_{j}\left[\frac{p_{x, i}(v)}{P_{j}}\right]^{-\sigma}
$$

In country $i$, the differentiated goods are produced by a continuum of identical firms with the same productivity level $\varphi_{i}$ and marginal $\operatorname{cost} \frac{1}{\varphi_{i}}, i=H, F$. Each firm has two options: it can produce for domestic market and/or export abroad. ${ }^{5}$ The fixed costs of these options are, respectively, $f$ and $f_{x} \cdot{ }^{6}$ Also, exporters have to pay per-unit trade costs $\tau>1$. Thus, in country $i$, firms set prices as

$$
p_{i}\left(\varphi_{i}\right)=\frac{1}{\rho \varphi_{i}} \text { and } p_{x, i}\left(\varphi_{i}\right)=\frac{\tau}{\rho \varphi_{i}}
$$

and maximize

$$
\max \left\{0, \pi_{i}\left(\varphi_{i}, P_{i}\right)\right\}+\max \left\{0, \pi_{j}\left(\frac{\varphi_{i}}{\tau}, P_{j}\right)\right\}, i \neq j,
$$

where $\pi_{i}\left(\varphi_{i}, P_{i}\right)$ is profit earned by firm from country $i$ in the domestic market with price index $P_{i}$, and $\pi_{j}\left(\frac{\varphi_{i}}{\tau}, P_{j}\right)$ is profit earned by an exporter from country $i$ to country $j .{ }^{7}$ In particular,

$$
\pi_{i}\left(\varphi_{i}, P_{i}\right)=p_{i}\left(\varphi_{i}\right) q_{i}\left(\varphi_{i}\right)-\frac{q_{i}\left(\varphi_{i}\right)}{\varphi_{i}}-f, \text { and } \pi_{j}\left(\frac{\varphi_{i}}{\tau}\right)=p_{x, i}\left(\varphi_{i}\right) q_{j}\left(\frac{\varphi_{i}}{\tau}\right)-\tau \frac{q_{j}\left(\frac{\varphi_{i}}{\tau}\right)}{\varphi_{i}}-f_{x}
$$

\footnotetext{
${ }^{3}$ Introducing differences in countries' size would not change the results, but complicates the analysis.

${ }^{4}$ Note that Venables (1987) considers a more general case, when $U=U(N, Q)$. In other words, he requires only the separability of the utility function between the numeraire commodity and the differentiated goods. We chose to specify the utility function to simplify the analysis. Our conclusions are unaffected by this simplification.

${ }^{5}$ Note that since firms in each country are the same, either all firms use the option or none of them does.

${ }^{6}$ The introduction of the differences in the fixed costs between countries does not change the results.

${ }^{7}$ It is easy to show that profits earned by an exporter from country $i$ to country $j$ with productivity level $\varphi_{i}$ equal to profits earned by a domestic firm from country $j$ with productivity level $\frac{\varphi_{i}}{\tau}$.
} 
Using the demand functions and the usual formulas for prices, it can be shown that

$$
\begin{aligned}
\pi_{i}\left(\varphi_{i}, P_{i}\right) & =\frac{r_{i}\left(\varphi_{i}, P_{i}\right)}{\sigma}-f=\frac{E_{i}\left(P_{i} \rho \varphi_{i}\right)^{\sigma-1}}{\sigma}-f, \\
\pi_{j}\left(\frac{\varphi_{i}}{\tau}, P_{j}\right) & =\frac{r_{j}\left(\frac{\varphi_{i}}{\tau}, P_{j}\right)}{\sigma}-f_{x}=\frac{E_{j}\left(P_{j} \frac{\rho \varphi_{i}}{\tau}\right)^{\sigma-1}}{\sigma}-f_{x},
\end{aligned}
$$

where $r_{i}\left(\varphi, P_{i}\right)$ is the revenue earned by a domestic firm from country $i$ with productivity $\varphi$, and $E_{i}$ is the expenditures on the differentiated goods in country $i, E_{i}=P_{i} Q_{i}=\beta(w L)=\beta L{ }^{8}$

\subsection{The Logic of Venables (1987)}

In Venables (1987) model, $f_{x}=0$. Thus, firms export as long as they make positive variable profits from the market. The crux of his argument can be seen from his Figure 1. This relates the price indices in the two countries to free entry condition for their firms. For each country, a unit decrease in the home price index (which reduces profitability in the home market) must be compensated for by more than a unit increase in the foreign price index to keep profits at zero. This is the case as transport costs make the home market more important than the foreign one. The intersection of these two zero profit conditions pins down the number of firms in each market.

Now consider an improvement in productivity on the part of home firms. Due to this, their ability to make profits is enhanced and their free entry line shifts inwards. But this reduces the price index at Home and raises it abroad as the other free entry line is downward sloping! But a higher price index abroad reduces foreign welfare and a lower price index at Home raises home welfare. The intuition is that higher domestic productivity makes Home a better place to locate so entry rises at home and falls abroad. Because of transport costs, this is good for Home consumers and bad for foreign ones as consumers get more from domestic firms than foreign ones.

\section{The Equilibrium with Fixed Costs of Exporting}

Now consider what the addition of fixed costs of exporting does. Firms can choose to export, to export and produce domestically, to only produce domestically, or not to produce any of the differentiated goods. Given free entry in each country and each market, profits from choosing any option cannot exceed zero. Thus, we can write four sets of conditions which define the equilibrium:

$$
\begin{aligned}
\pi_{H}\left(\varphi_{H}, P_{H}\right) & \leq 0, \pi_{H}\left(\varphi_{H}, P_{H}\right) M_{H H}=0, \\
\pi_{F}\left(\frac{\varphi_{H}}{\tau}, P_{F}\right) & \leq 0, \pi_{F}\left(\frac{\varphi_{H}}{\tau}, P_{F}\right) M_{H F}=0, \\
\pi_{F}\left(\varphi_{F}, P_{F}\right) & \leq 0, \pi_{F}\left(\varphi_{F}, P_{F}\right) M_{F F}=0, \\
\pi_{H}\left(\frac{\varphi_{F}}{\tau}, P_{H}\right) & \leq 0, \pi_{H}\left(\frac{\varphi_{F}}{\tau}, P_{H}\right) M_{F H}=0 .
\end{aligned}
$$

These are the familiar zero profit and complementary slackness conditions. If profits are positive, entry will occur and compete these profits away. If firms at Home sell in the domestic market $\left(M_{H H}>0\right)$, then $\pi_{H}\left(\varphi_{H}, P_{H}\right)$ must be zero. If profits are negative, then $M_{H H}=0$. Similarly for the other three sets of conditions.

\footnotetext{
${ }^{8}$ Note that due to free entry, consumers' income in country $i$ is equal to labor payments, $w L$, which is equal to $L$, since wage $w$ is normalized to 1 by the choice of the numeraire commodity.
} 
Figure 1: The equilibrium outcomes when $\mathrm{A}>1$

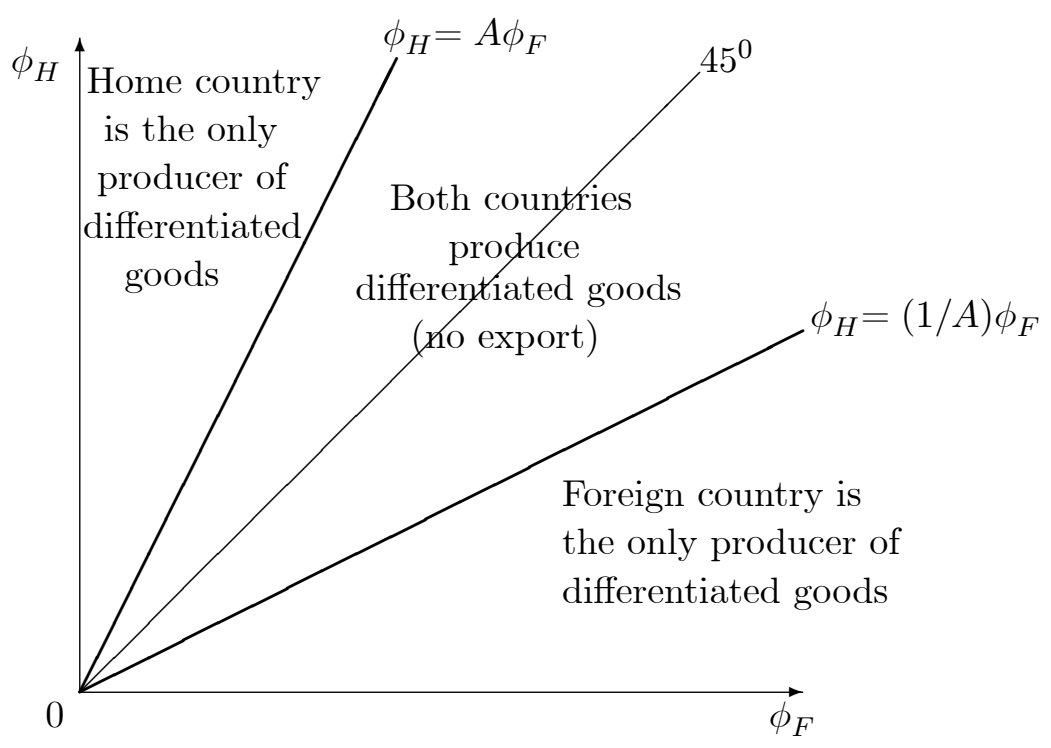

Note that if firms from both countries sell in the home country's market, i.e., $M_{H H}>0$ and $M_{F H}>0$, then from (3) and (6)

$$
\varphi_{H}=\left[\tau\left(\frac{f_{x}}{f}\right)^{1 /(\sigma-1)}\right]^{-1} \varphi_{F}=A^{-1} \varphi_{F},
$$

where $A=\tau\left(\frac{f_{x}}{f}\right)^{1 /(\sigma-1)}$. This is depicted by the straight line below the 45 degree line when $A>1$ in Figure 1 and by the straight line above the 45 degree line when $A<1$ in Figure 2. In Figure 1, the line is below the 45 degree one as foreign firms need to be quite productive to make up for the disadvantages they face in the home market: namely, the high fixed costs of exports and transport costs. In Figure 2, the line is above the 45 degree one as foreign firms can be relatively unproductive and still export to the home market since fixed costs of exports are low.

Above the line given by (7), home productivity is so high than foreign firms cannot make up this disadvantage and do not sell abroad but home firms sell in their domestic market. Below this line, foreign firms sell in the home market, but home firms cannot sell in their own market.

Similarly, if firms from both countries sell in the foreign country's market, i.e., $M_{F F}>0$ and $M_{H F}>0$, then from (5) and (4)

$$
\varphi_{H}=\left[\tau\left(\frac{f_{x}}{f}\right)^{1 /(\sigma-1)}\right] \varphi_{F}=A \varphi_{F} .
$$

This is depicted by the straight line above the 45 degree line when $A>1$ in Figure 1 and by the straight line below the 45 degree line when $A<1$ in Figure 2. In Figure 1, the line is above the 45 degree one as home firms need to be quite productive to make up for the disadvantages they face in the foreign market: namely, the high fixed costs of exports and transport costs. In Figure 2 , the low fixed cost of exporting give them an advantage in the foreign market and they need not 
Figure 2: The equilibrium outcomes when $\mathrm{A}<1$

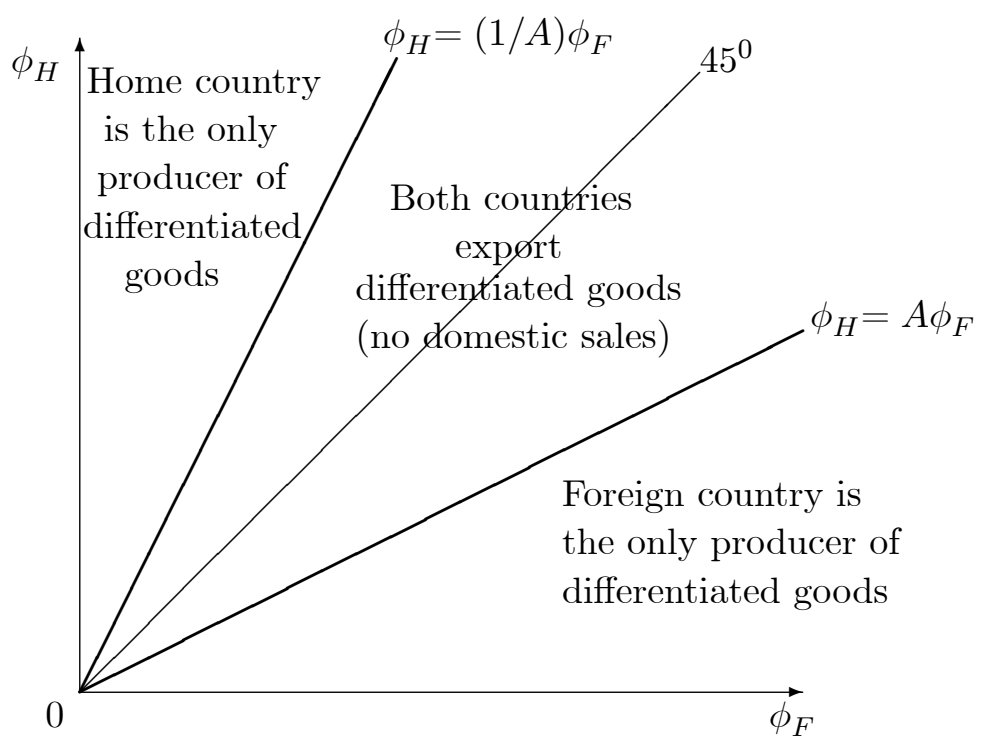

be so productive.

Above the line given by (8), home productivity is so high that home firms can sell in the foreign market but foreign firms cannot sell there. Below this line, foreign firms sell in the foreign market, but home firms cannot sell abroad. These arguments allow us to label the different regions in Figures 1 and 2 as done.

If $A>1$, the costs of exporting are high relative to the cost of production for the domestic market, i.e., it is easier to become a domestic producer than to be an exporter, so that no firm exports its variety of the differentiated good without selling it in the domestic market. If $A<1$, the costs of producing for the domestic market are higher than those of exporting, so that no firm produces a differentiated good domestically without exporting it abroad. ${ }^{9}$

To complete the analysis, assume that $A=1$. In this case only when $\varphi_{H}=\varphi_{F}$, is it possible for both countries to produce differentiated goods. If there are productivity differences, the less productive country specializes in the homogeneous good.

\section{Technological Progress and Welfare}

The indirect utility function can be written as

$$
U_{i}=\frac{(1-\beta)^{1-\beta} \beta^{\beta}}{\left(P_{i}\right)^{\beta}} .
$$

What happens to it when the technological progress in the differentiated good sector occurs in the home country, i.e., if $\varphi_{H}$ rises?

\footnotetext{
${ }^{9}$ Note that since the second case is at odds with the empirical evidence, we can make the usual assumption that costs of exporting are high enough so that exporters always produce for the domestic market. We chose not to do so to derive more general results.
} 
If $A>1$, an increase in $\varphi_{H}$ cannot not reduce welfare in the foreign country. If $\varphi_{H}<A \varphi_{F}$, the foreign country is the only producer of the differentiated goods so that an increase in $\varphi_{H}$ has no effect on the price index in the foreign country, and hence, no effect on its welfare or on the welfare of the home country. If $\varphi_{H}>A \varphi_{F}$, the home country is the only producer of the differentiated goods and an increase in $\varphi_{H}$ reduces the price index in the home and foreign countries, and hence, raises their welfare. Similar arguments can be made to show that there are no welfare losses at Home or abroad if $A \leq 1$. As a result, we can conclude that technological progress in any country cannot reduce welfare of its trading partner.

\section{Conclusion}

In this paper we have shown that the results obtained by Venables (1987) strongly depend on his assumption that there are no fixed costs of trade. The introduction of fixed costs of exporting, while making the model more consistent with the empirical evidence, leads to the opposite conclusion that technological progress in one country cannot harm the welfare of its trading partner. However, his results can be obtained in a richer model. Demidova (2005) shows that technological progress in one country can lead to welfare losses abroad, if we relax the assumption that firms are homogeneous, and allow for firm heterogeneity as in Melitz (2003).

\section{References}

[1] Demidova, S. (2005). Productivity Improvements and Falling Trade Costs: Boon or Bane? Mimeo.

[2] Dixit, A. and J. Stiglitz (1977). Monopolistic Competition and Optimum Product Diversity. American Economic Review, 67, pp.297-308.

[3] Melitz, M.J. (2003). The Impact of Trade on Intra-Industry Reallocations and Aggregate Industry Productivity. Econometrica, 71, pp.1695-1725.

[4] Roberts, M.J. and J.R. Tybout (1997). The Decision to Export in Colombia: An Empirical Model of Entry with Sunk Costs. American Economic Review, 87, pp.545-64.

[5] Venables, Anthony (1987). Trade and Trade Policy with Differentiated Products: A Chamberlinian-Ricardian Model. The Economic Journal, 97, pp.700-717. 